\title{
The Effect of Ecklonia stolonifera Extracts on Blood Flow and Serum Lipid Level in Ovariectomized Rats
}

Young Kyoung Kim, Min Hee Jeon, Yong Soo Park, Hyun Jung Hwang, Sang-Hyeon Lee', Sung Gu Kim², Yuck Young $\mathrm{Kim}^{3}$ and Mihyang Kim*

\author{
Department of Food and Nutrition, Silla University, Busan 617-738, Korea \\ ${ }^{1}$ Department of Pharmaceutical Engineering Silla University, Busan 617-736, Korea \\ ${ }^{2}$ Bioport Korea Co., Marine Bio-industry Department Center, Busan 619-912, Korea \\ ${ }^{3}$ IS Food Co, Marine Bio-industry Department Center, Busan 619-912, Korea
}

Received September 16, 2010 /Accepted November 25, 2010

\begin{abstract}
Estrogen deficiency in peri- and postmenopausal women results in variety of neurovegetative, psychic and somatic symptoms, and may contribute to severe diseases within the aged female population. Ecklonia stolonifera (ES) is an edible brown algae traditionally used in fishery towns in Far East Asia. This study was performed to investigate the effects of ES extracts on blood flow and serum lipid concentration in ovariectomized rats. Weight-matched female Sprague-Dawley strain rats were assigned to four groups. Three groups were surgically ovariectomized (OVX). The fourth group was sham operated. Rats were randomly assigned to the following groups: sham-operated rats (Sham), ovariectomized control rats (OVX-CON), ovariectomized rats supplemented with ES extract at $50 \mathrm{mg} / \mathrm{kg}$ bw/day (OVX-ES50) and ovariectomized rats supplemented with ES extract at $200 \mathrm{mg} / \mathrm{kg}$ bw/day (OVX-ES200). Serum total cholesterol and triglyceride contents decreased in the sham group compared to the OVX-CON group. Six weeks feeding of ES extract resulted in a significant $(p<0.05)$ lowering of serum triglyceride and a lowering tendency of total cholesterol level. The level of Hdl-cholesterol in serum increased by supplementation of ES extracts at $50 \mathrm{mg} / \mathrm{kg}$ and $200 \mathrm{mg} / \mathrm{kg} \mathrm{bw} /$ day $(p<0.05)$. Blood passage time of the ES extracts-supplemented group was higher than the OVX-CON group. The ability of platelet aggregation of groups treated with ES extracts was less than that of the OVX-CON group. These results suggest that the beneficial effects of ES extract may be used to possibly improve on the metabolic syndrome of menopausal women.
\end{abstract}

Key words : Ecklonia stolonifera, platelet aggregation, blood flow, serum lipids, ovariectomized rats

\section{서 론}

과학과 문명의 발달로 점차 인간의 평균 수명이 연장되어 노년층 인구의 증가와 함께 중년 이후의 삶이 길어지고 실질 적으로 여성의 갱년기는 인간 수명이 연장됨으로 인해 삶 중 에서 $1 / 3$ 을 차지한다는 것이 문제점으로 대두되고 있다. 이러 한 상황으로 인해 폐경 후 여성의 건강과 삶의 질에 대한 관심 이 높아지고 있으며 이는 궁극적으로 폐경기 여성의 건강관리 가 의학적, 사회적 측면에서도 중요한 관심사임을 알 수 있다. 폐경 후 증후군은 다른 원인들도 복합적으로 작용하는 것으로 알려지고 있으나, 주로 여성 호르몬인 estrogen 부족이 중요한 원인이라고 알려지고 있다[5]. 폐경기 증상은 estrogen 분비 감소의 발현시기에 따라 달리 나타나는데, 급성증상은 혈관 운동장애로 인한 안면홍조, 야간 발한, 불면증이 나타나고, 신 경내분비계 증상으로는 정서의 변화, 기억장애, 집중장애 등

*Corresponding author

Tel : +82-51-999-5620, Fax : +82-51-999-5457

E-mail : mihkim@silla.ac.kr
이 심리적인 문제와 동반하여 나타난다. 아급성 증상은 폐경 후 시간이 경과함에 따라 그 빈도가 증가하는데, 비뇨 생식기 계의 위축과 결체조직으로부터의 collagen 소실에 의한 피부 위축, 관절통, 요실금 등의 증상을 들 수 있다. 만성 후유증으 로는 골다공증, 고지혈증 및 치매 등을 들 수 있다[43]. 이러한 만성질환은 한번 발생하면 치명적이거나 장기적으로 영향을 미치고, 노년기 삶의 질에도 영향을 주므로 중년기 여성의 건 강관리는 매우 중요하다[27,4]. 관상동맥질환은 고혈압, 고지 혈증, 당뇨, 흡연 등의 위험 요소와 관련된 질환으로 폐경 이후 관상동맥질환은 급격히 증가하며, 수술에 의한 그 위험도는 2.5배 이상 크다[29]. 이러한 폐경기 이후 문제를 감소시키기 위하여 합성 estrogen을 포함한 호르몬 보충요법(hormone replacement therapy, HRT)이 사용되어 왔다. 호르몬 보충요법 은 안면홍조 등과 같은 폐경기 증상의 완화와 골다공증의 치 료와 예방에 효과가 있으며, 심혈관계 질환을 $30-50 \%$ 감소시 키는 것으로 보고된 바 있다[38]. 그러나 미국 국립보건원 $(\mathrm{NIH})$ 의 연구를 비롯한 장기간의 추적연구에서 호르몬 보충 요법이 유방암, 정맥혈전색전증 뿐 아니라 관상동맥질환, 뇌 졸중 등을 오히려 증가시킨다는 보고는 호르몬요법의 위험성 
을 경고하였다[10,41]. 해조류는 식이성 섬유소인 복합다당류 를 다량 함유하고 있을 뿐 아니라 여러 비타민과 무기질이 비교적 풍부하고 그 독특한 맛과 향기가 우수한 알칼리성 기 호식품으로서 가치가 높다[39]. 또한 해조류는 소화율이 낮아 서 열량원으로서의 가치는 적지만 섬유성 식품으로 위에 포만 감과 통변을 조절하는 효과[26,30] 뿐만 아니라 항암[6,22], 항 당뇨[24,25] 항고지혈증[14,18], 항산화[7,36] 및 항노화[15] 등 여러 생리적 효능을 지니고 있다. 곰피(Ecklonia stolonifera)는 동해안과 남해안을 따라 분포하며, 해안선을 따라 2-10 m 수심 의 해안에서 자라는 다년생의 다시마과에 속하는 갈조류[31] 로서, 우리나라에서는 다시마, 미역 등과 함께 식용으로 이용 되어 왔으며, 전통적으로는 이러한 해조류들이 항마취제, 항 염증제 및 습진, 통풍, 담석 등의 치료에 민간요법으로 사용되 어 오고 있다[13]. 곰피에 대한 선행연구로는 곰피로부터 분리 한 phloroglucinol이 흰쥐의 acetaminophen 대사효소활성에 미치는 영향[32] 및 곰피 메탄올 추출물의 xanthine oxidase 저해작용[21]을 들 수 있다. 또한 곰피 메탄올 추출물의 아질산 염 소거활성, 항산화 활성에 대한 연구[33] 뿐만 아니라, 곰피 에탄올 추출물의 항균활성[19], 항돌연변이 활성[37]에 대한 연구결과도 보고 되어 있다. 갈조류 중 감태가 estrogen 활성이 높은 것으로 알려져 있으나[16], 갈조류인 곰피가 갱년기 장애 를 유도하였을 때 나타나는 estrogen 분비 감소로 인한 심혈관 계 질환 발병 위험률에 대한 영향은 연구된 바가 없다. 따라서 본 연구에서는 실험동물로써 흰쥐를 이용하여 인위적으로 갱 년기를 유도한 후 곰피 추출물의 영향을 혈중지질 농도, 혈소 판 응집력 및 혈액 유동성을 통하여 그 효과를 검토하고자 하 였다.

\section{재료 및 방법}

\section{추출물의 제조}

본 실험에 사용한 곰피(Ecklonia stolonifera, ES)는 2009년에 전라도에서 채취된 것을 구입하여 물로 8 9회 씻어 내서 염 분과 불순물을 제거하고 동결 건조 후 분쇄하여 사용하였다. $100 \mathrm{~g}$ 의 건조 시료에 $80 \%$ ethanol 21 를 가해 $80^{\circ} \mathrm{C}$ 에서 3회 추출하여 감압 농축기로 농축한 후 분말로 조제하여, 실제로 동물실험에서는 투여량 $1 \mathrm{ml}$ 중 체중 $\mathrm{kg}$ 당 $50 \mathrm{mg}$ 및 200 $\mathrm{mg}$ 되도록 증류수에 용해하여 사용하였다.

\section{실험동물}

실험동물은 $200 \mathrm{~g}$ 되는 9주령의 Sprague-Dawley계 암컷 흰 쥐를 (주)오리엔트로부터 구입하여 1주일간 적응시킨 뒤 실험 에 사용하였다. 적응 후 난괴법에 의해 4 군으로 나누어 $24 \pm 2^{\circ} \mathrm{C}$, 습도 $55 \sim 60 \%, 12$ 시간 조명주기의 조건 하에서 6 주간 사육하였다. 실험군은 비 난소절제군(SHAM), 난소절제 대조 군(OVX-CON), 난소 절제 후 곰피 추출물 $50 \mathrm{mg} / \mathrm{kg}$ 투여군 (OVX-ES50) 및 $200 \mathrm{mg} / \mathrm{kg}$ 투여군(OVX-ES200)으로 나누어 실험하였다(Table 1). 실험시료는 증류수로 용해하여 경구 투 여기구를 이용하여 $1 \mathrm{ml}$ 씩 경구 투여 하였으며, 대조군은 동일 용량의 증류수를 투여하였다. 체중은 실험 사육 기간 중에 격 일로 일정 시간에 측정하고, 식이 섭취량은 매일 식이 잔량을 측정하여 산출하였다. 수술 후 사육환경은 수술 전과 동일하 게 조성하였다.

\section{난소절제시술}

1 주일 동안 주위환경에 적응시켜 난괴법에 의해 군을 나누 어 난소 절제 수술을 실시하였다. 수술은 ether 마취 후 심마취 기에 이르면 늑골하부를 절개하여 난소를 제거하고 절개 부는 봉합하였다. 시술 후 3 일부터 매일 곰피 시료를 경구 투여 하 였다.

\section{혈액 및 장기 채취}

혈액은 실험동물을 해부 전 24시간 절식 시킨 후 ether 마취 하에서 개복하여 대동맥에서 채취하였고, 심장, 신장, 부신, 자궁, 폐 및 간 조직은 적출하여 주위의 지방과 물기를 제거하 여 무게를 측정한 후 실험 시까지 $-70^{\circ} \mathrm{C}$ 에서 보관하였다.

\section{혈청 중의 지질농도 분석}

채취한 혈액은 실온에서 30 분 방치 후 $3,000 \mathrm{rpm}$ 에서 10 분 간 원심분리 $\left(4^{\circ} \mathrm{C}\right)$ 하여 혈청을 분리하였다. 혈청 중 중성지방, 총콜레스테롤, $\mathrm{Hdl}$ 콜레스테롤 농도는 자동 측정용 slide (FUJI FILM, Japan)를 이용하여 Dry chemistry analyzer 3500i (Fuji, Japan)로 측정하였다.

\section{혈류 측정}

혈류 측정은 전혈을 사용 하였고, 채취한 혈액을 헤파린 처 리된 튜브를 사용하여 응고를 방지한 후, Micro Channel

Table 1. Experimental design of animals

\begin{tabular}{ll}
\hline Group (No) & Treatment \\
\hline SHAM (7) & operated rats \\
OVX-CON (7) & ovariectomized rats \\
OVX-ES50 (7) & ovariectomized rats supplemented Ecklonia stolonifera ethanol extract $50 \mathrm{mg} / \mathrm{kg} \mathrm{bw} / \mathrm{day}$ \\
OVX-ES200 (7) & ovariectomized rats supplemented Ecklonia stolonifera ethanol extract $200 \mathrm{mg} / \mathrm{kg} \mathrm{bw} /$ day \\
\hline
\end{tabular}

${ }^{a}$ No: Number of rats. 
Array Flow Analyzer KH-6 (MC Lab, Japan)을 이용하여 채 취한 혈액 $100 \mu \mathrm{l}$ 를 주입하여 측정하였다.

\section{혈소판 응집력 분석}

Ether 마취 후 개복하여 대동맥으로부터 채혈하여 $3.2 \%$ sodium citrate 용액과 1:9의 비율로 혼합한 뒤 $1,100 \mathrm{rpm}$ 에서 10 분간 원심분리하여 상층의 PRP (platelet rich plasma)를 취 하고, $3,000 \mathrm{rpm}$ 에서 10 분간 더 원심분리하여 상층에 혈장을 제거한 후 EDTA를 포함하는 washing buffer $(138 \mathrm{mM} \mathrm{NaCl}$, $2.7 \mathrm{mM} \mathrm{KCl}, 12 \mathrm{mM} \mathrm{NaHCO}, 0.36 \mathrm{mM} \mathrm{NaH} \mathrm{PO}_{4}, 5.5 \mathrm{mM}$ glucose, $1 \mathrm{mM}$ EDTA, pH 6.5) $5 \mathrm{ml}$ 를 가하고 섞어주어 혈소 판을 재 현탁시켰다. 이 혈소판을 다시 $3,000 \mathrm{rpm}$ 에서 10 분간 원심분리 한 후, 세척액을 버리고 혈소판을 위의 방법으로 한 번 더 세척하였다. 세척 후 suspending buffer $(138 \mathrm{mM} \mathrm{NaCl}$, $2.7 \mathrm{mM} \mathrm{KCl}, 12 \mathrm{mM} \mathrm{NaHCO}, 0.36 \mathrm{mM} \mathrm{NaH}_{2} \mathrm{PO}_{4}, 5.5 \mathrm{mM}$ glucose, $0.49 \mathrm{mM} \mathrm{MgCl}$, $0.25 \%$ Gelatin, $\mathrm{pH}$ 7.4)로 재 현탁 시켜 $3,000 \mathrm{rpm}$ 에서 10 분간 원심분리한 후 다시 suspending buffer로 현탁시켜 washed platelet을 조제하였다. Washed platelet는 suspending buffer로 희석하여 혈소판 수가 $5 \times 10^{8} / \mathrm{ml}$ 이 되도록 하였고, 응집유도제로 collagen을 $2.5 \mathrm{\mu l}$ 가하여 5 분간 반응시켜, Whole blood lumi-aggregometer (Chrono-log, U.S.A)를 사용하여 $37^{\circ} \mathrm{C}$ 에서 혈소판 응집을 측 정하였다.

\section{통계처리}

본 실험에 대한 모든 실험의 결과는 mean $\pm \mathrm{SD}$ 치로 나타내 었고, 통계적 유의성은 SPSS version 17.0 통계 프로그램을 이
용하여 상호비교 하였다.

\section{결 과}

\section{식이 섭취량, 체중 증가량 및 장기 중량}

Table 2는 실험기간 동안 실험동물의 체중 증가량 및 식이 효율을 나타낸 것이다. 최종 체중량은 곰피 추출물 투여군이 비투여군에 비해 높은 결과가 나타났으나 집단 간 유의성은 나타나지 않았다. 반면, 체중증가량 및 식이효율에 있어서는 오히려 난소 절제 후 추출물을 투여하지 않은 OVX-CON군이 추출물 투여군보다 증가하는 경향을 나타내었다. 한편, 실험 후 각 실험동물의 장기 중량을 나타낸 Table 3에서 간, 부신, 폐와 비장 조직의 무게는 각 군 간 차이를 나타내지 않았다. 일반조직은 난소 절제에 의해 중량 변화와 같은 영향을 받지 않는 것으로 알려져 있으나, 자궁의 경우 체내 에스트로겐의 작용 여부를 잘 나타내주는 것으로, 난소 절제한 OVX-CON군 과 곰피 추출물을 투여한 군에서 SHAM군에 비해 감소하는 경향을 나타내었다.

\section{혈청 중 중성지방 및 총콜레스테롤 함량}

혈청 중 중성지방과 총콜레스테롤 변화를 Table 4 에 나타내 었다. 총콜레스테롤 함량의 경우, 난소를 절제하여 인위적으 로 갱년기를 유도한 OVX-CON군은 난소를 절제하지 않은 $\mathrm{SHAM}$ 군과 비교해 증가하는 경향을 나타내었다. 이에 반해 난 소 절제 후 곰피 추출물을 투여한 군은 OVX-CON군에 비해 감소하였고, 특히 OVX-ES200군은 SHAM군과 비슷한 수준을 보였다. 혈총 중 중성지방 함량의 경우 난소 절제한 OVX-CON

Table 2. Body weight gain, food intake and food efficiency ratio of rats supplement with Ecklonia stolonifera ethanol extracts for 6 weeks

\begin{tabular}{lcccc}
\hline Group $^{\mathrm{a}}$ & Final body weight $(\mathrm{g})$ & Body Weight gain $(\mathrm{g} /$ day) & Food intake $(\mathrm{g} /$ day) & Food efficiency ratio (FER) \\
\hline SHAM & $304 \pm 31.8^{\mathrm{b}}$ & $4.13 \pm 3.09$ & $18.31 \pm 1.56$ & $0.23 \pm 1.53$ \\
OVX-CON & $333 \pm 28.61$ & $5.34 \pm 4.41$ & $20.95 \pm 2.49$ & $0.25 \pm 2.46$ \\
OVX-ES50 & $355.93 \pm 17.79$ & $5.02 \pm 5.41$ & $21.02 \pm 1.83$ & $0.24 \pm 1.83$ \\
OVX-ES200 & $358.15 \pm 18.32$ & $4.99 \pm 3.13$ & $21.25 \pm 1.54$ & $0.23 \pm 1.56$ \\
\hline
\end{tabular}

${ }^{a}$ See the legend of Table 1.

${ }^{\mathrm{b}}$ The results are mean $\pm \mathrm{SD}$ for 7 rats in each group.

${ }^{c}$ FER: Weight gain (g/day)/Food intake (g/day)

Table 3. Organ weight of rats on supplementation of Ecklonia stolonifera ethanol extracts

\begin{tabular}{llllllcc}
\hline Group $^{1)}$ & Liver & Heart & Lung & Spleen & Adrenal & Kidney & Uterus \\
\hline SHAM & $8.37 \pm 0.86^{2)}$ & $0.93 \pm 0.11$ & $1.18 \pm 0.08$ & $0.5 \pm 0.07$ & $0.07 \pm 0.03$ & $1.81 \pm 0.13$ & $0.6 \pm 0.15^{* 3)}$ \\
OVX-CON & $8.06 \pm 0.41$ & $1.01 \pm 0.12$ & $1.42 \pm 0.14$ & $0.57 \pm 0.05$ & $0.06 \pm 0.02$ & $1.74 \pm 0.11$ & $0.11 \pm 0.01$ \\
OVX-ES50 & $8.32 \pm 1.29$ & $0.97 \pm 0.1$ & $1.55 \pm 0.5$ & $0.59 \pm 0.1$ & $0.07 \pm 0.02$ & $1.7 \pm 0.11$ & $0.12 \pm 0.03$ \\
OVX-ES200 & $7.86 \pm 0.63$ & $1.03 \pm 0.14$ & $1.42 \pm 0.32$ & $0.66 \pm 0.13$ & $0.07 \pm 0.03$ & $1.77 \pm 0.19$ & $0.1 \pm 0.02$ \\
\hline
\end{tabular}

${ }^{a}$ See the legend of Table 1.

${ }^{\mathrm{b}}$ The results are mean $\pm \mathrm{SD}$ for 7 rats in each group.

${ }^{c}{ }^{*} p<0.05$, significantly different from OVX-CON group. 
Table 4. Contents of total cholesterol and triglyceride in the serum of ovariectomized rats with Ecklonia stolonifera ethanol extracts

$(\mathrm{mg} / \mathrm{dl})$

\begin{tabular}{lcc}
\hline Group $^{\mathrm{a}}$ & $\mathrm{T}-\mathrm{CHO}$ & $\mathrm{TG}$ \\
\hline SHAM & $115.00 \pm 3.74^{\mathrm{b}}$ & $74.25 \pm 6.70^{*_{\mathrm{c}}}$ \\
OVX-CON & $132.25 \pm 16.46$ & $102.00 \pm 7.26$ \\
OVX-ES50 & $126.75 \pm 7.63$ & $86.75 \pm 11.64$ \\
OVX-ES200 & $112.75 \pm 7.89$ & $78.75 \pm 9.84^{*}$ \\
\hline
\end{tabular}

${ }^{a}$ See the legend of Table 1.

${ }^{\mathrm{b}}$ The results are mean \pm SD for 7 rats in each group.

${ }^{c}{ }^{*} p<0.05$, significantly different from OVX-CON group.

군이 난소를 절제하지 않은 SHAM군과 비교해 증가하였고, 난소절제 후 곰피 추출물을 투여한 OVX-ES50군과 OVXES200군 모두 OVX-CON군보다 감소하였다. 특히 난소 절제 후 추출물을 $200 \mathrm{mg} / \mathrm{kg}$ /day 투여한 군은 OVX-CON군보다 유의적으로 감소하는 결과가 나타났다.

혈청 중 $\mathrm{Hdl}-$ 콜레스테롤, $\mathrm{Ldl}-$ 콜레스테롤, 동맥경화지수 및 심혈관위험 지수

곰피 추출물을 6주간 투여한 흰쥐의 혈청 중 $\mathrm{Hdl}$-콜레스테 롤 및 Ldl-콜레스테롤의 함량, 동맥경화지수와 심혈관위험지 수에 대한 곰피 추출물의 영향을 나타낸 결과는 Table 5 와 같 다. 혈청 중 $\mathrm{Hdl}$-콜레스테롤 농도는 난소를 절제한 OVX-CON 군에 비해 $\mathrm{SHAM}$ 군이 유의적으로 $(p<0.05)$ 증가하였으며, 곰 피 추출물 투여에 의해서 Hdl-콜레스테롤은 OVX-CON군과 비교해서 유의적으로 $(p<0.05)$ 증가하는 것을 볼 수 있었다. 한 편, 혈청 중 $\mathrm{Ldl}$-콜레스테롤 함량은 $\mathrm{OVX}-\mathrm{CON}$ 군의 경우 $87.99 \pm 16.39 \mathrm{mg} / \mathrm{dl}$ 으로 SHAM $(40.10 \pm 3.43 \mathrm{mg} / \mathrm{dl})$ 군에 비하 여 증가하였으나, 곰피 추출물 투여에 의해 감소되었으며 특 히 OVX-ES200군에서 유의적으로 감소하는 경향이 나타났다. 동맥경화지수인 $\mathrm{AI}$ 지수는 난소 절제를 한 OVX-CON군에 비 하여 난소 절제 후 곰피 추출물을 투여한 OVX-ES500 및 OVX-ES200군의 동맥경화지수가 유의적으로 감소되었다. 또 한 심혈관위험지수를 나타내는 $\mathrm{CRF}$ 는 난소를 절제한
OVX-CON군에서 정상군인 SHAM군에 비하여 높은 수치를 나타내었으나 곰피 추출물 투여로 인해 유의적으로 감소하는 결과를 나타내었다.

\section{혈류 개선 효과}

혈류의 흐름에 미치는 곰피 추출물의 영향을 검토하기 위해 각 군의 혈액을 채취하여 항응고제인 헤파린 처리 후, 혈액의 유동성을 시각적이고 정량적으로 인식하여 혈액의 속도를 측 정할 수 있는 Micro channel array flow analyzer (MC-FAN) 를 이용하여 일정한 압력으로 인해 혈액이 모세관을 25,50 , $75,100 \mu 1$ 통과하는 시간을 측정하였다(Fig. 1). 실험결과 혈액 $25 \mu \mathrm{l}$ 통과 시 각 군간에 별다른 차이가 나타나지 않았으나, $50 \mu \mathrm{l}$ 부터 OVX-CON군의 모세관 통과 시간이 지연되기 시작 하였으며 $100 \mu \mathrm{l}$ 통과 시에는 난소를 절제하지 않은 SHAM군 에 비해 현저하게 지연되는 결과가 나타났다. 한편 난소 절제 후 곰피 추출물을 투여한 OVX-ES50 및 OVX-ES200군의 경우 OVX-CON군보다 빠른 시간에 모세관을 통과하였다.

\section{혈소판 응집에 미치는 영향}

\section{난소 절제로 인해 에스트로겐이 결핍되어 혈청 중 지질 함}

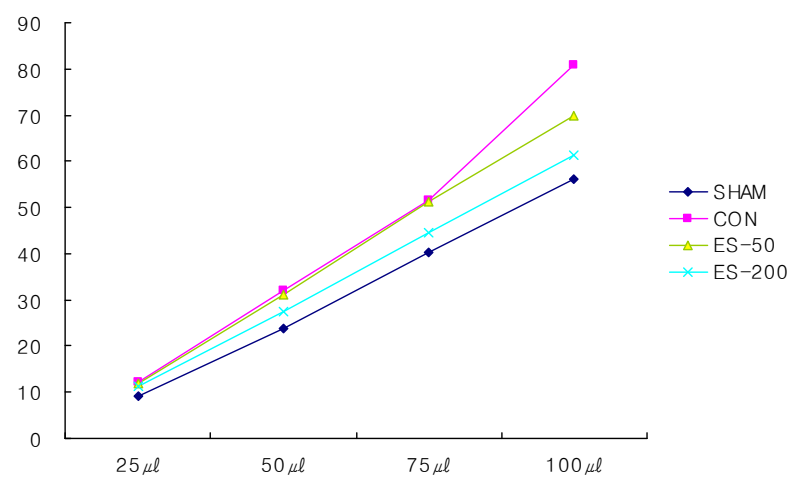

Fig. 1. Effect of Ecklonia stolonifera ethanol extracts on micro channel array in ovariectomized rats.

Table 5. Contents of triglyceride, total cholesterol, Hdl-cholesterol, Ldl-cholesterol and atherogenic index (AI), cardiac risk factor $(\mathrm{CRF})$ in the serum of ovariectomized rats with Ecklonia stolonifera ethanol extracts

\begin{tabular}{lcccc}
\hline Group $^{\mathrm{a}}$ & $\mathrm{Hdl}$ & $\mathrm{Ldl}^{\mathrm{b}}$ & $\mathrm{AI}^{\mathrm{c}}$ & $\mathrm{CRF}^{\mathrm{d}}$ \\
\hline SHAM & $89.75 \pm 2.63^{\mathrm{e}^{* \mathrm{f}}}$ & $40.10 \pm 3.43^{*}$ & $0.28 \pm 0.04^{*}$ & $1.28 \pm 0.04^{*}$ \\
OVX-CON & $64.66 \pm 3.62$ & $87.99 \pm 16.39$ & $1.05 \pm 0.30$ & $2.05 \pm 0.30$ \\
OVX-ES50 & $76.90 \pm 2.09^{*}$ & $67.20 \pm 11.31$ & $0.65 \pm 0.13^{*}$ & $1.65 \pm 0.13^{*}$ \\
OVX-ES200 & $83.00 \pm 5.89^{*}$ & $45.50 \pm 12.57^{*}$ & $0.37 \pm 0.16^{*}$ & $1.37 \pm 0.16^{*}$ \\
\hline
\end{tabular}

\footnotetext{
${ }^{a}$ See the legend of Table 1.

${ }^{\mathrm{b}}$ Ldl cholesterol=\{total cholesterol-(Hdl-cholesterol- triglyceride/5) $\}$.

c AI (atherogenic index)=(total cholesterol-Hdl-cholesterol)/Hdl-cholesterol.

${ }^{\mathrm{d}} \mathrm{CRF}$ (cardiac risk factor)=total cholesterol/Hdl-cholesterol.

e The results are mean \pm SD for 7 rats in each group.

f ${ }^{*} \mathrm{p}<0.05$, significantly different from OVX-CON group.
} 
Table 6. Effect of Eckonia stolonifera ethanol extracts against collagen induced platelet aggregation

\begin{tabular}{lccc}
\hline Group $^{\mathrm{a}}$ & Amplitude $(\%)$ & Slop $(\Omega / \mathrm{min})^{\mathrm{b}}$ & Lag time $(\mathrm{sec})$ \\
\hline SHAM & $105.19 \pm 3.75^{\mathrm{c}^{*} \mathrm{~d}}$ & $144.06 \pm 3.32$ & $21.38 \pm 4.26^{*}$ \\
OVX-CON & $110.88 \pm 2.92$ & $143.38 \pm 7.59$ & $14.56 \pm 3.01$ \\
OVX-ES50 & $109.81 \pm 1.56$ & $135.69 \pm 5.46$ & $18.75 \pm 5.86^{*}$ \\
OVX-ES200 & $101.63 \pm 4.75^{*}$ & $129.81 \pm 6.67^{*}$ & $20.50 \pm 2.39^{*}$ \\
\hline
\end{tabular}

\footnotetext{
${ }^{a}$ See the legend of Table 1.

${ }^{\mathrm{b}}$ Initial slop is ohm change for the first on minute.

${ }^{c}$ The results are mean \pm SD for 7 rats in each group.

${ }^{\mathrm{d}}{ }^{*} p<0.05$, significantly different from OVX-CON group.
}

량이 증가한 상태에서 곰피 추출물의 투여로 인한 혈소판 응 집 억제효과를 검토하기 위해 washed platelet을 분리하고 collagen $2 \mu 1$ 로 혈소판 응집을 유도하였다. 그 결과 곰피 추출 물을 투여한 군이 OVX-CON군에 비해 혈소판 응집을 억제하 는 것으로 나타났다(Table 6). 응집율을 나타내는 amplitude (\%)는 OVX-CON군이 SHAM군과 비교하여 증가하였으나, 곰 피 추출물 투여에 의해서 감소하는 경향을 나타내었다. 반응 이 일어나기 시작될 때의 속도를 나타내는 $\operatorname{slop}(\Omega / \mathrm{min})$ 은 난소를 절제하지 않은 SHAM $(144.06 \pm 3.32 \Omega / \mathrm{min})$ 군과 난소 를 절제한 OVX-CON $(143.38 \pm 7.59 \Omega / \mathrm{min})$ 군이 비슷한 경향 을 나타내었으나, 곰피 추출물을 투여한 OVX-ES50 $(135.69 \pm 5.46 \Omega / \mathrm{min})$ 군과 OVX-ES200 $(129.81 \pm 6.67 \Omega / \mathrm{min})$ 군 의 경우 유의적으로 $(p<0.05)$ 감소하는 결과가 나타났다. 응집 시간을 나타내는 lag time $(\mathrm{sec})$ 에서 OVX-CON군은 SHAM군 과 비교하여 혈액의 응집에 걸리는 시간이 단축되어 난소 절 제로 인해 혈소판 응집이 촉진되었다. 한편, 곰피 추출물 투여 군인 OVX-ES50 $(18.75 \pm 5.86 \mathrm{sec})$ 및 OVX-ES200 (20.50 \pm 2.39 $\mathrm{sec})$ 군은 OVX-CON군에 비하여 유의적으로 $(p \times 0.05)$ 응집 시 간이 증가하여 응집이 지연되는 결과를 나타내었다.

\section{고 찰}

본 연구에서는 실험동물로써 흰쥐를 이용하여 인위적으로 갱년기를 유도한 후 갈조류인 곰피 추출물의 영향을 실험동물 의 체중, 혈중지질 농도, 혈소판 응집력 및 혈액 유동성을 통하 여 그 효과를 검토하고자 하였다.

난소 절제에 의한 estrogen 분비 감소가 체중 증가를 초래한 다는 보고와 마찬가지로[1,2,42], 본 실험에서도 난소를 절제한 OVX-CON군이 난소를 절제하지 않은 SHAM군에 비해 체중 이 증가하였다. 일반적으로 난소절제로 인한 estrogen 분비 부족은 지방조직의 지단백 리파아제(lipoprotein lipase)의 활 성을 저하시키고 호르몬 민감성 리파아제(hormone sensitive lipase) 활성을 증가시켜 체지방 축적을 억제한다고 알려져 있 다[34,40]. OVX-CON군이 SHAM군에 비해 체중이 증가하는 것은 여성호르몬 부족으로 인한 체내 지방조직의 증가에 의한 것이며, 또한 지방조직에서도 여성호르몬을 생성 할 수 있는
기능을 가지고 있기 때문에, 지방조직에서 난소의 기능을 대 체 하고자 하는 체내의 비상대책으로 여겨진다. 그러나 난소 절제 후 곰피를 투여한 모든 군에서 SHAM군과 비교해 높은 체중 증가량을 나타내어 곰피 추출물이 체중감소에는 크게 영향을 미치지 않았다. 한편, 조직중량을 측정한 결과에서 일 반조직은 난소 절제에 의한 영향을 별로 받지 않으나 자궁 무게는 체내 에스트로겐의 작용 여부를 잘 나타내주는 것으 로, 난소 절제한 OVX-CON군과 곰피 추출물을 투여한 군에서 $\mathrm{SHAM}$ 군과 비해 감소하였다. 이는 난소 절제로 인한 자궁의 퇴화로 인한 것으로 추측되며, 곰피 추출물의 투여가 자궁의 무게에는 영향을 미치지 않았다. 혈청 중 총콜레스테롤과 중 성지방 함량(Table 4)에서 난소 절제에 의해 OVX-CON군이 난소를 절제하지 않은 SHAM군과 비교해 증가하였고, 난소절 제 후 곰피 추출물을 투여한 OVX-ES50군과 OVX-ES200군 모 두 OVX-CON군보다 감소하였다. 특히 중성지방 함량에서 OVX-ES200군은 OVX-ES200군과 비교하여 유의적으로 감소 하는 결과를 나타내었다. 콜레스테롤 농도의 분포를 보면, 건 강한 젊은 여성의 경우 같은 나이의 남성에 비해, 총콜레스테 롤, Ldl-콜레스테롤 그리고 중성지방 농도는 낮고 $\mathrm{Hdl}$-콜레스 테롤 농도는 상대적으로 높으나, 폐경에 이르게 되면 중성지 방과 $\mathrm{Hdl}$-콜레스테롤 농도는 대체로 변화가 없고 총콜레스테 롤과 Ldl-콜레스테롤 농도는 증가되어 폐경기 이후 혈관 관련 질환의 발병률이 높아지는 원인으로 작용하고 있다[28]. 해조 류 등의 수산식품이 동맥경화, 심근경색, 고혈압, 협심증, 뇌졸 중, 당뇨병 등의 만성 퇴행성 질환으로 알려진 성인병의 예방 과 치료에 아주 효과적이란 사실이 과학적으로 입증되고 있다 [8]. 따라서 곰피 추출물의 투여가 난소 절제에 의해 estrogen 분비가 저하된 상태에서 지질대사에 유익한 영향을 주어 심혈 관계질환 개선에 도움을 줄 것으로 기대된다. 혈청 중 $\mathrm{Hdl}$-콜 레스테롤 농도는 난소를 절제한 OVX-CON군에 비해 SHAM 군이 유의적으로 $(p<0.05)$ 증가하였으며, 곰피 추출물 투여에 의해서 Hdl-콜레스테롤은 OVX-CON군과 비교해서 유의적으 로 $(p<0.05)$ 증가하는 것을 볼 수 있었다(Table 5). 한편, 혈중 Ldl-콜레스테롤 함량은 OVX-CON군의 경우 증가하였으나 곰 피 추출물 투여에 의해 감소되었으며 특히 OVX-ES200군에서 유의적으로 감소하는 경향이 나타났다. 폐경 이전의 여성은 
항동맥 경화 인자인 $\mathrm{Hdl}$-콜레스테롤의 수준이 남성보다 높고, Ldl-콜레스테롤의 수준이 낮게 나타나지만[20], 폐경 이후에 는 난포호르몬 결핍에 의한 난소기능의 저하로 에스트로겐 자극과 LDL 수용체의 활동이 감소되어 Ldl-콜레스테롤의 수 준이 증가하고, $\mathrm{Hdl}$-콜레스테롤의 수준이 낮아짐으로써[11] 폐경기 여성들의 심혈관계 질환의 유병율을 증가시키는 원인 이 된다. Ldl-콜레스테롤은 macrophage에서 생성된 활성산 소, free radical, 내피세포의 lipoxygenase 및 과산화지질에 의하여 쉽게 산화되어 산화된 형태의 Ldl-콜레스테롤 (oxidized- Ldl-cholesterol)을 생성한다. 산화된 Ldl-콜레스테 롤은 내피세포에 축적되어 거대 거품세포(foam cell)를 형성하 며, 이 과정에서 일부 세포는 사멸되고 이 거대 거품세포가 증가하면서 지방층이 동맥벽에 쌓여 동맥경화가 일어나게 된 다[23]. 총콜레스테롤과 $\mathrm{Hdl}$ 콜레스테롤의 수치로 환산한 동 맥경화지수(AI) 및 심혈관위험지수(CRF)는 일반적으로 동맥 경화 및 순환기계질환의 발병의 위험도를 알리는 위험 지수로 서 널리 이용되고 있다[3,35]. $\mathrm{AI}$ 지수는 난소 절제를 한 OVX-CON군에 비하여 곰피 추출물을 투여한 군은 동맥경화 지수가 감소되었다. 이는 $\mathrm{Hdl}$ 콜레스테롤의 증가와 총콜레스 테롤 농도 감소에 의한 것으로 곰피 추출물이 동맥경화 위험 요소를 감소 시킬 수 있음을 추측할 수 있다. 또한 심혈관위험 지수를 나타내는 CRF는 난소를 절제한 OVX-CON군에서 정 상군인 SHAM군에 비하여 높은 수치를 나타내었으나 곰피 추출물 투여로 인해 유의적으로 감소하는 경향을 나타내었다. 혈액에는 매우 다양한 혈액세포, 조절물질, 영양소 등이 흐르 게 되는데 혈액응고반응으로 인해 혈관이 손상되면 제 기능을 다하지 못하여 혈액의 항상성을 잃게 된다. 혈관손상의 여러 요인 중 estrogen의 결핍은 혈액 중에 높은 Ldl-콜레스테롤과 중성지방, 총콜레스테롤을 생성하게 되고 혈관에 이러한 침착 물이 축적하게 되면 혈관벽이 두꺼워져 탄력성이 감소함과 동시에 혈관이 좁아져 혈액의 흐름을 방해하게 된다. 이러한 과정의 반복으로 폐경기 여성의 동맥경화, 심근경색 등의 심 혈관계질환이 증가하게 된다[17]. 본 실험의 결과 갱년기 장애 를 유도한 흰쥐에 곰피 추출물의 투여가 Hdl-콜레스테롤, Ldl콜레스테롤, $\mathrm{CRF}$ 및 $\mathrm{AI}$ 지수가 감소하는 경향을 보였으며 이 는 곰피가 동맥경화 및 고지혈증의 발병률을 낮추고 개선에 유용한 효과를 가지는 것으로 생각된다. 혈액의 유동성에 미 치는 곰피 추출물의 영향을 검토한 결과 SHAM군이 OVX-CON군에 비해 빠른 시간에 모세관을 통과하였다. 이는 난소 절제에 의한 혈청 중 지질조성의 변화에 따른 결과로 보여진다. 한편 곰피 추출물 투여군의 경우 OVX-CON군보다 빠른 시간에 통과하였다. 이상으로 난소 절제로 인해 혈장 내 혈액응고인자(coagulation factors)의 지나친 활성화 및 혈소 판 응집 촉진으로 혈류의 모세관 통과 시간이 늦어 졌으나 곰피 추출물의 투여로 인해 혈류의 속도가 빨라짐을 볼 수 있고, 이는 곰피가 혈액의 유동성에 좋은 영향을 줄 것으로
기대되어진다. 혈전은 일반적으로 인체의 혈관이 손상을 받아 출혈이 일어난 후 혈액이 혈관 또는 조직 내에서 응고 됨으로 써 생성된다[9]. 혈전은 병적 상태나 기계적 손상 및 여러 화학 물질 등에 의해 혈관 벽이 손상을 받게 되면 혈관의 subendothelium에 collagen이 노출되어 여기에 혈소판이 점착하 게 된다. 점착된 혈소판은 $\mathrm{ADP}$, thrombin 및 $\mathrm{Ca}^{++}$등을 유리 하고 $5-\mathrm{HT}$ 와 $\mathrm{TxA}_{2}$ 를 생성하여 주위의 혈소판을 활성화시켜 응집하게 된다. 이렇게 생긴 응집물이 혈류에 의해 떨어져 나 간 것을 혈전(thrombus)이라 하고, 혈전은 혈류를 따라 흐르다 가 미세혈관을 막아 심근경색, 허혈 등의 혈행 장애를 유발하 게 된다[12]. 본 연구에서는 난소 절제로 인해 estrogen이 결핍 되어 혈청 중 지질 함량이 증가한 상태에서 곰피 추출물의 투여로 인한 혈소판 응집 억제효과를 검토하였다. 그 결과 곰 피 추출물을 투여한 군이 OVX-CON군에 비해 혈소판 응집을 억제하는 것으로 나타났다(Table 6). 응집율을 나타내는 amplitude (\%) 및 반응이 일어나기 시작될 때의 속도를 나타내는 $\operatorname{slop}(\Omega / \mathrm{min})$ 은 곰피 추출물 투여에 의해 유의적으로 $(p<0.05)$ 감소하는 결과가 나타났다. 응집시간을 나타내는 lag time $(\mathrm{sec})$ 의 경우 곰피 추출물 투여에 의해 응집이 지연되는 결과 를 나타내었고, 이러한 결과는 곰피 추출물이 collagen으로 인 한 응집을 효율적으로 억제시키는 것으로 생각할 수 있다. 이 상의 결과로 미루어 곰피가 동맥경화증, 혈전증 등의 혈관 관 련성 질환 예방에 효과가 있을 것으로 기대되며, 기능성 식품 및 식재료로 사용하기 위한 앞으로의 더욱 구체적인 연구가 필요한 것으로 사료된다.

\section{References}

1. Abe, T., J. M. Chow, J. M. Lean, and T. J Chambers. 1993. Estrogen does not restore bone list after ovariectomy in the rat. J. Bone Miner. Res. 8, 831-838.

2. Aitken, J. M., E. Armstrong, and J. B. Anderson. 1972. Osteoporosis after ovarietomy in the mature female rat and the effect of estrogen and/or progesterone replacement therapy in its prevention. J. Endocrinol. 55, 79-87.

3. Assmann, G. H., S. A. Eckardstein, and Y. Huang. 1996. High-density lipoprotein cholesterol as a predictor of coronary heart disease risk. The PROCAM experience and pathophysiological implications for reverse cholesterol transport. Supplement 124, 11-20.

4. Back, S. S. 1998. An analysis of the relationship of menopausal symptoms of midlife women between urban area and rural area. Korean J. Women Health Nurs. 4, 332-347.

5. Campbell, S, and M. I. Whitehead. 1982. Potency and hepatocellular effects of estrogens. pp. 103-125, Lancaster, England. MTP Press.

6. Cho, K. J., Y. S. Lee, and B. H. Ryu. 1990. Antitumor effect and immunology activity of seaweeds toward sarcoma- 180 . J. Korean. Fish Soc. 23, 345-352.

7. Cho, S. H., S. E. Kang, J. Y. Cho, A. R. Kim, S. M. Park, 
Y. K. Hong, and D. H. Ahn. 2007. The antioxidant properties of brown seaweed (sargassum siliquastrum) extracts. J. Med Food 10, 479-485.

8. Choi, J. H. and D. W. Kim. 1999. Effect of Brown Algae (Undaria pinnatifida)-Noodle on lipid metabolism in serum of SD-Rats. J. Korean Fish Soc. 32, 42-49.

9. Furie, B. and B. C. Furie. 1988. The molecular basis of blood coagulation. Cell 53, 505-518.

10. Grady, D., D. Herrington, V. Bittner, R. Blumenthal, M. Davidson, M. Hlatky, J. Hsia, S. Hulley, A. Herd, S. Khan, L. K. Newby, D. Waters, E. Vittinghoff, and N. Wenger. 2002. Cardiovascular disease outcomes during 6.8 years of hormone therapy: heart and estrogen/progestin replacement study follow-up (HERS II). J. American Med Association 288, 4957-4963.

11. Grundy, S. M. and M. Scott. 1986. Cholesterol and coronary heart disease. J. American Med Association 256, 2849-2858.

12. Hawiger, J. 1993. Platelets: receptors, adhesion, secretion. FEBS Letters 331, 200.

13. Hoppe, H. A. and T. Levring. 1982. Marine algae in Pharmaceutical Science 2. pp. 309, In Hoppe, H. A. and T. Levring (eds.). Walter de Gruyter, Berlin and New York.

14. Joo, D. S., J. K. Lee, Y. S. Chol, S. Y. Cho, Y. K. Je, and J. W. Choi. 2003. Effects of seatangle oligosaccharide drink on serum and hepatic lipids in rats fed a hyperlipidemic diet. J. Korean Soc. Food Sci. Nutr. 32, 1364-1369.

15. Kang, H. S., H. R. Kim, D. S. Byun, B. W. Son, T. J. Nam, and J. S. Choi. 2004. Tyrosinase inhibitors isolated from the edible brown alga Ecklonia stolonifera. Arch Pharm. Res. 27, 1226-1232.

16. Kang, S. R. and M. H. Kim. 2009. The effect of Eckonia cava extracts on bone turnover markers in ovariectomized rats. J. Life Sci. 19, 1841-1846.

17. Keiko, N., N. Mieko, A. Nobuo, I. Yoji, K. Imako, and K. Yuji. 2003. Red blood cell deformability in relation to gender, age, blood pressure, obesity, serum lipids, alcohol consumption and smoking. Japanese J. Hyg. 58, 287-297.

18. Kim, H. S. and G. A. Kim. 1998. Effects of the feeding Hijikia fusi-forme (Harvey) Okamura on lipid composition of serum in dietary hyperlipidemic rats. J. Korean Soc. Food Sci. Nutr. 27, 718-723.

19. Kim, J. H., D. S. Lee, C. W. Lim, H. Y. Park, and J. H. Park. 2002. Antibacterial activity of Sea-mustard, Laminaria japoniva extracts on the cariogenic bacteria, streptococcus mutans. J. Korean Fish Soc. 35, 191-195.

20. Kim, M. H. 1987. An internal disease of women. Dankwang Press Co, Seoul.

21. Kim, O. K., T. G. Lee, Y. B. Park, D. C. Park, Y. W. Lee, S. G. Yeo, I. S. Kim, Y. H. Park, and S. B. Kim. 1999. Inhibition of Xanthine Oxidase by Seaweed Extracts. J. Korean Soc. Food Sci. Nutr. 25, 1069-1073.

22. Kim, Y. M., J. R. Do, D. S. Kim, and J. H. Park. 2006. Cytotoxicities of hydrolyzed crude laminaran from Eisenia biscyclis on the SNU-1, Hela and SW cells. Korean Food Sci. Technol. 793-798.

23. La Rosa, J. C., D. Hunninghake, D. Bush, M. H. Criqui, G.
S. Getz, and A. M. Gotto. 1990. The cholesterol facts. A summary of the evidence relating dietary fats, serum cholesterol, and coronary heart disease. A joint statement by the America Heart Association and the National Heart, Lung and Blood Institute. The Task Force on Cholesterol Issue, Am Heart Assoc. Circul. 81, 1721-1733.

24. Lee, H. S., M. S. Choi, Y. K. Lee, S. H. Park, and Y. J. Kim. 1996. A study on the development of high-fiber supplements for the diabetic patients (2)-Effect of seaweed supplementation on the lipid and glucose metabolism in streptozotocin-induced diabetic rats. J. Korean Soc. Food Sci. Nutr. 29, 296-306.

25. Lee, K. S., J. S. Se, and Y. S. Choi. 1998. Effect of sea tangle and hypoglycemic agent on lipid metabolism in diabetic rats. J. Korean Soc. Food Sci. Nutr. 27, 960-967.

26. Lee, J. G., Y. S. Lim, D. S. Joo, and I. H. Joung. 2002. Effects of diet with seatangle (Kjellmaniella crassifolia) on calcium absorption, serum composition and feces in rats. J. Korean Fish Soc. 35, 601-607.

27. Lee, J. H., Y. G. Jung, H. M. Park, J. S. Park, and S. K. Yeom. 2002. A study on Climacteric Symptoms in Korean Midlife Women. J. Korean Soc. of Menopause 6, 142-156.

28. Mendelsohn, M. E. and R. H. Karas. 1994. Estrogen and the blood vessel wall. Curr. Poin. Cardiol. 9, 619-626.

29. Moore, A. O., P. M. Mullins, and M. C. Pugh. Hormonal replacement therapy. In; Dipiro JT, Talbert RL, Hayes PE, Yee GC, Matzke GR, Posey LM; Pharmacotherapy, A pathophy siological approach.

30. Oh, H. K. and H. S. Lim. 2007. Effects of the products of raw sea tangle on chronic idiopathic constipation. J. Korean Soc Food Sci. Nutr. 36, 720-726.

31. Park, C. S., E. K. Hwang, S. J. Lee, K. W. Roh, and C. H. Sohn. 1994. Age and growth of Ecklonia stolonifera Okamura in Pusan Bay, Bull. J. Korean Fish Soc. 27, 390-396.

32. Park, J. C., J. M. Hur, J. G. Park, H. J. Kim, S. S. Chun, J. S. Choi, and J. W. Choi. 2000. Effect of Phloroglucinol Isolated from Ecklonia stolonifera on the Acetaminophen -Metabolizing Enzyme System in Rat. J. Korean Soc. Food Sci. Nutr. 29, 448-452.

33. Park, Y. B. 2005. Determination of nitrite scavenging activity of seaweed. J. Korean Soc. Food Sci. Nutr. 34, 1293-1296.

34. Ramirez, M. E., M. P. McMurry, G. A. Wiebke, K. J. Felton, and K. Ren. 1997. Evidence for sex steroid inhibition of lipoprotein lipase in men; comparison of abdominal and femoral adipose tissue. Metabolism 46, 179-185.

35. Rosenfeld, L. 1989. Early methods in the diagnosis of atherosclerosis. Lipoprotein Analysis 113, 1101-1110.

36. Ruberto, G., M. T. Baratta, D. M. Biondi, and V. Amico. 2001. Antioxidant activity of extracts of the marine algae genus Cystoseira in a micellar model system. J. Appl. Phycol. 13, 403-407.

37. Ryu, B. H., B. H. Chi, D. S. Kim, and M. S. Ha. 1986. Dismutagenic Effect of Extracts Obtained from seaweed. $J$. Korean Fish Soc. 19, 502-508.

38. Stampfer, M. H. and G. A. Colditz. 1991. Estrogen replacement therapy and coronary heart disease: a quantitative as- 
sessment of the epidemiologic evidence. Prev. Med 20, 47-63.

39. Sung, J. H., Y. S. Ha, M. H. Im, J. G. Im, and K. S. Kang. 2002. Seaweed and health. In: Foods and Health. pp. 190, Hyungseol Press Co, Seoul.

40. Valette, A., K. M. Meignen, L. Mercier, J. G. Liehr, and J. Boyer. 1986. Effect of 2-fluoroestradiol on lipid metabolism in the ovariectomized rat. J. Steroid Biochem 25, 575-578.

41. Writing group for the WHI investigators. 2002. Risks and benefits of estrogen plus progestin in healthy post- menopausal women: principal results from the women's health initiative randomized controlled trial. J. American Med Association 288, 321-333.

42. Wronski, T. J., M. Cintron, and L. M. Dann. 1988. Temporal relationship between bone loss and increased bone turnover ovariectomized rats. Calcif. Tissue Int. 43, 179-183.

43. Yoon, B. G., D. K. Kim, J. W. Kim, D. S. Choi, D. S. Bae, and D. L. Na. 2003. Association between osteoporosis and alzheimer's disease in women. J. Korean Menopause 9, 20-24.

\section{초록 : 곰피 추출물이 난소를 절제한 흰쥐의 혈액 유동성 및 혈중 지질함량에 미치는 영향}

\section{김영경 $\cdot$ 전민희 $\cdot$ 박용수 $\cdot$ 황현정 $\cdot$ 이상현 ${ }^{1} \cdot$ 김성구 ${ }^{2} \cdot$ 김육용 $\cdot$ 김미향*}

(신라대학교 의생명과학대학 식품영양학과, ${ }^{1}$ 신라대학교 의생명과학대학 제약공학과, ${ }^{2}$ (주) 바이오포트 코리 아, ${ }^{3}$ (주) 아이에스 푸드)

갱년기의 여성에는 여러 폐경 증후들이 나타나는데, 특히 estrogen의 감소로 인한 혈중 지질 조성의 변화 등으 로 심혈관계 질환의 발병율이 높아지게 된다. 본 연구에서는 실험동물로써 흰쥐를 이용하여 인위적으로 갱년기 를 유도한 후 갈조류인 곰피 추출물의 영향을 혈중지질 농도, 혈소판 응집력 및 혈액 유동성을 통하여 그 효과를 검토하고자 하였다. 그 결과 갱년기유도로 인하여 증가된 혈청 중 중성지방 및 총콜레스테롤 함량은 곰피 추출물 투여에 의해 저하되었으며, 특히 곰피 추출물 $200 \mathrm{mg} / \mathrm{kg} \mathrm{bw} /$ day 투여는 중성지방 함량을 유의적으로 감소시키 는 결과를 나타내었다. Ldl-콜레스테롤, 동맥 경화지수(AI) 및 심혈관위험지수(CRF) 또한 곰피 추출물 투여에 의 해 저하되었다 한편 $\mathrm{Hdl}$ 콜레스테롤 농도는 난소절제에 의해 감소하였으나, 곰피 추출물을 투여에 의해 증가되 었다. 혈액의 유동성에 곰피 추출물의 효과를 실험한 결과 난소 절제에 의해 혈액의 점도가 증가하여 유동성이 저하되었으나, 곰피 추출물 투여로 인해 유동성이 향상됨을 알 수 있었다. 또한 난소 절제에 의해 혈소판 응집능 이 증가하였으나, 곰피 추출물 투여로 인해 완화되는 효과를 볼 수 있었다. 이상의 결과로부터 갱년기에 나타날 수 있는 혈중 지질 변화에 대하여 곰피 추출물이 지질 및 혈행 개선 효과를 나타내었으며, 특히 곰피 추출물 200 $\mathrm{mg} / \mathrm{kg} \mathrm{bw} / \mathrm{day}$ 투여는 모든 항목에서 유의성 있는 결과를 나타내어 곰피가 심혈관 관련성 질환 예방에 도움을 줄 것으로 기대된다. 